\title{
Autoradiography, Gross
}

National Cancer Institute

\section{Source}

National Cancer Institute. Autoradiography, Gross. NCI Thesaurus. Code C19231.

A technique that uses X-ray film to visualize gross anatomical structures that have been radioactively labeled. 